\title{
Impacts of Artisanal Refining Activities on Soil and Water Quality in Parts of Okrika and Ogu-Bolo Areas of Rivers State, Nigeria
}

\author{
Nwankwoala $\mathrm{HO}^{1 *}$, Harry $\mathrm{MT}^{1}$, Amangabara $\mathrm{GT}^{2}$ and Warmate $\mathrm{T}^{3}$ \\ ${ }^{1}$ Department of Geology, University of Port Harcourt, Nigeria \\ ${ }^{2}$ Department of Environmental Technology, Federal University of Technology, Owerri, Nigeria
}

${ }^{3}$ Geostrat International Services Limited, Port Harcourt, Nigeria

\begin{abstract}
This study aims at the assessment of the impacts of artisanal refining of crude on soil and water quality in parts of Okrika and Ogu-Bolo areas of Rivers State, Nigeria. Standard sampling methods were used in the study. A total number of sixteen (16) sampling points were selected using random sampling techniques for the water points and soil samples within Ogu-Bolo and Okrika. Water and soil samples were analyzed in the laboratory using standard methods. The ArcGIS version 10.3, ENVI version 4.7, Surfer 10, SPSS 22 and Microsoft Enterprise were used for the interpretation. The Digital Elevation Model (DEM) was created from the elevation data obtained from Short Radar Thematic Mapper (SRTM) satellite image and contour extracted from the topographic map. The influence of the soil type, slope, flow accumulation and flow direction of the study area was used to delineate the level of contaminant plume. This was generated from the DEM using the ArcGIS 10.3 3-D analyst tool function. A water Quality index rating of 1 was measured in the study area which is an indication that the water is very bad. Also, the physio-chemical analysis on soil and water revealed poor water and soil. Water analysis showed high concentration of $\mathrm{Fe}$ and $\mathrm{Zn}$ which made the water in such area unsuitable for drinking. Also, the soil samples recorded high levels of crude content from $1 \mathrm{~m}$, with concentration reducing with depth up to $3 \mathrm{~m}$. A general contamination map of Okrika/Ogu-Bolo was modelled, indicating the contamination rating of total land mass of the study area, with $23.59 \mathrm{~km}(5.71 \%)$ rated very good, while $85.65 \mathrm{~km}(20.71 \%)$ were rated good. Also, $140.37 \mathrm{~km}(33.95 \%)$ had only showed moderate level of contamination while $112.56 \mathrm{~km}(27.22 \%)$ recorded bad level of contamination, with $51.29 \mathrm{~km}(12.40 \%)$ of the total land mass having very bad contamination record. Water quality assessment should be carried out regularly to determine any future pollution of the water. It is recommended that artisanal refining activities in the area should be discouraged to avoid further contamination in the area.
\end{abstract}

Keywords: Aquifer vulnerability; Plume; Contaminant; Water quality; Artisanal refining; Soil

\section{Introduction}

Contamination of groundwater is on a steady rise particularly in our urban cities where so many industrial activities are carried out, increase in population, land that are used for commercial agriculture, poor sanitary system and other factors causing environmental degradation $[1,2]$. The contaminated Groundwater unlike surface water contamination is considered a more difficult problem because of the difficulty in its early detection and skill required for prediction of its rate and path of movement $[3,4]$ and the extent of the impact. Also, to determine the concentration of these contaminants in the groundwater will depend on the quantity and nature of the elements that are found in it, which can be brought in naturally or through human actions and spread across the geological stratification of the area.

Petroleum refining is responsible for the inputs of gaseous, solid and liquid wastes into the environment [5]. Some of these wastes are said to contain poisonous substances, and if brought into the environment, they will possibly cause damage to the environment, constantly staying deposits, found in living things could build-up in adipose tissues and also move up the trophic web or chain [6]. In Nigeria, the Niger Delta region is believed to be the centre of natural and crude oil with numerous networks of product pipelines (both on and under the earth surface) completely across the entire region, and has resulted in the destruction of oil and gas pipelines, refining these products locally and the related environmental dangers which are obvious societal problems.

In the study area, some hand dug wells and deep wells (boreholes) were abandoned due to variations of the physico-chemical properties of groundwater. Also, reports of oil spills and complaints associated with groundwater contamination have increased in Ogu-Bolo and Okrika. This study therefore, evaluates the vulnerability of the groundwater within the study area.

\section{The study area}

The study area (Figure 1) is located in the Okrika, and Ogu-Bolo Local Government Area of Rivers State. It is readily accessible by a network of roads and footpaths and accessible to ships, boats, and canoes through the Bonny River and its tributaries. The study area is confined within the humid-hot equatorial climate, [7]. The average annual temperature is between $180^{\circ} \mathrm{C}$ to $220^{\circ} \mathrm{C}$ with annual range of about $200^{\circ} \mathrm{C}$. It is known for having two main seasons, the dry season and the wet season. The dry season begins from November and ends in March, while the wet stretches from mid-March to October. Fresh water is generally supplied by heavy precipitation estimated to have met annual rainfall above $2600 \mathrm{~mm}[7,8]$. The mean annual rainfalls within the past ten years, from 1997 to 2007, in Port Harcourt have shown notable variation. However, the maximum rainfall recorded

${ }^{*}$ Corresponding author: Nwankwoala HO, Department of Geology, University of Port Harcourt, Nigeria, Tel: +23484817941; E-mail: nwankwoala_ho@yahoo.com

Received July 29, 2017; Accepted September 03, 2017; Published September 07, 2017

Citation: Nwankwoala HO, Harry MT, Amangabara GT, Warmate T (2017) Impacts of Artisanal Refining Activities on Soil and Water Quality in Parts of Okrika and Ogu-Bolo Areas of Rivers State, Nigeria. J Environ Anal Toxicol 7: 503. doi: 10.4172/2161-0525.1000503

Copyright: @ 2017 Nwankwoala HO, et al. This is an open-access article distributed under the terms of the Creative Commons Attribution License, which permits unrestricted use, distribution, and reproduction in any medium, provided the original author and source are credited. 
Citation: Nwankwoala HO, Harry MT, Amangabara GT, Warmate T (2017) Impacts of Artisanal Refining Activities on Soil and Water Quality in Parts of Okrika and Ogu-Bolo Areas of Rivers State, Nigeria. J Environ Anal Toxicol 7: 503. doi: 10.4172/2161-0525.1000503

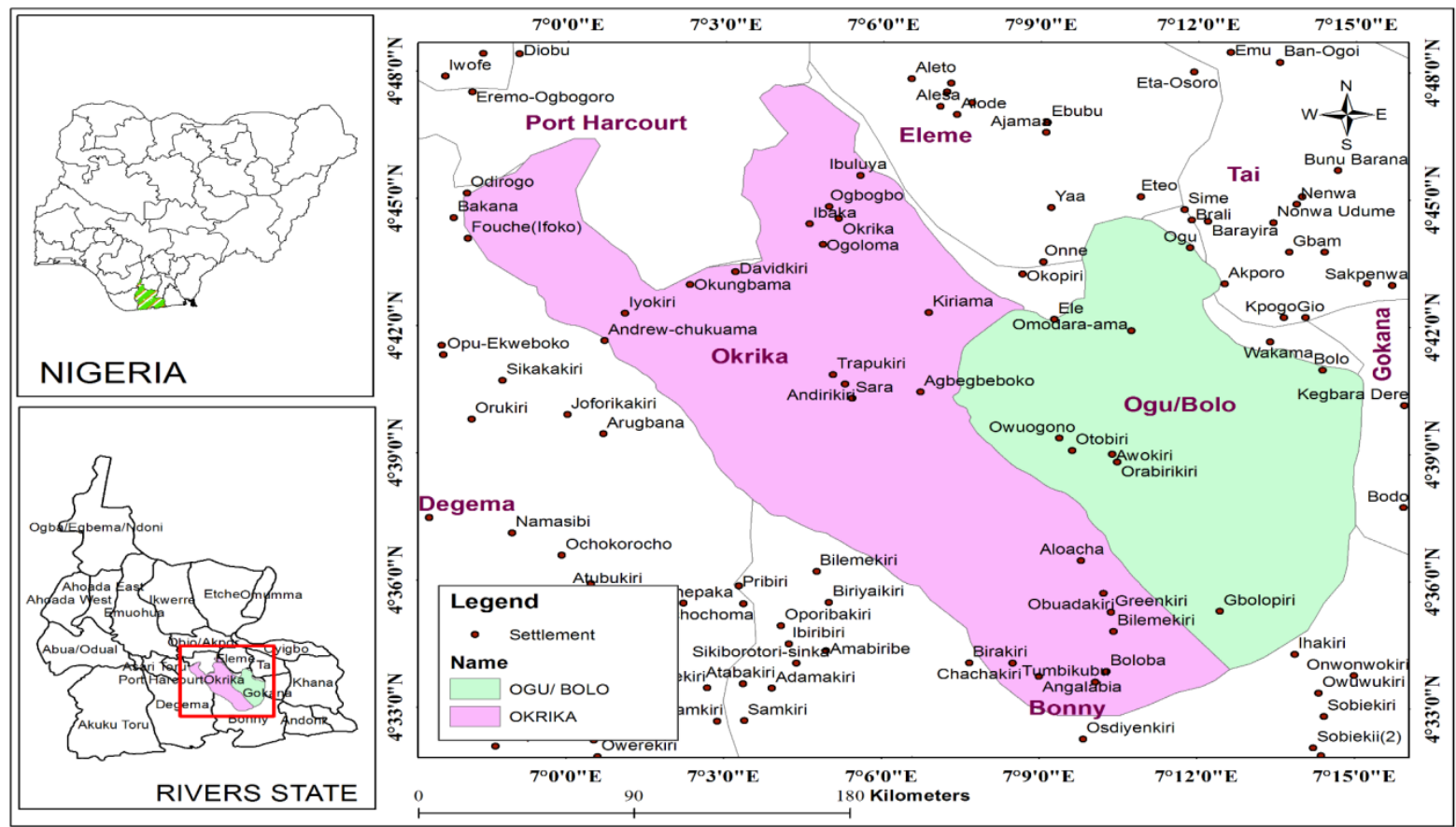

Figure 1: Generalized Map of Ogu-Bolo and Okrika.

within the years under review was in September 2006, with the mean annual rainfall within the periods (1997-2007) estimate to be $4455 \mathrm{~mm}$. The peaks of the rains occur in the months of June, July, September and October. The most significant factor that influences rainfall within this area is the tropical marine air mass, moisture. Laden air blows from the sea at least for ten months in a year that is, stretching from February to November. The counter air mass known as the tropical continental air mass blows from the Sahara Desert with dry and dusty characteristics. It is usually experienced in the place of study between December and January. The relative humidity is very high all through the year, and it is greater than $80 \%$ [9]. Bonny River and its tributaries and the creeks are accountable for the drainage around the deltaic plain belt area. The dockyard creek in the south, Amadi and Okpoka creeks in the east the channel of Bonny River (Port Harcourt Harbour) by the west drain the area. These creeks flow in the N-S direction into the bonny river, which eventually flow to the west. Each of the creeks that border Port Harcourt area can be subdivided into three sections, the head water are usually fresh water streams, the down streams which are saline and the brackish water area in between them (Figures 2 and 3$)$.

\section{Methods of Study}

A total number of sixteen (16) sampling points were selected using random sampling techniques used in selecting the water points (wells, boreholes) and soil samples within Ogu- Bolo and Okrika. The map required for this study was acquired with the use of Geographic Information System (GIS). Table 1 depicts the coordinates of location of soil samples while Table 2 shows the water sample coordinate locations. To delineate the study area, the administrative map that covers the area of study was geo-coded with a minimum Root Mean Square (RMS) error of 0.00005. Subsequently, the subset output were digitized using on-screen method. The digitized products were overlain on each other, while a frame marking out the region of interest (ROI) i.e., Ogu-Bolo and Okrika political boundary which lies between latitude $4^{\circ} 48^{\prime} 21.885^{\prime \prime} \mathrm{N}$

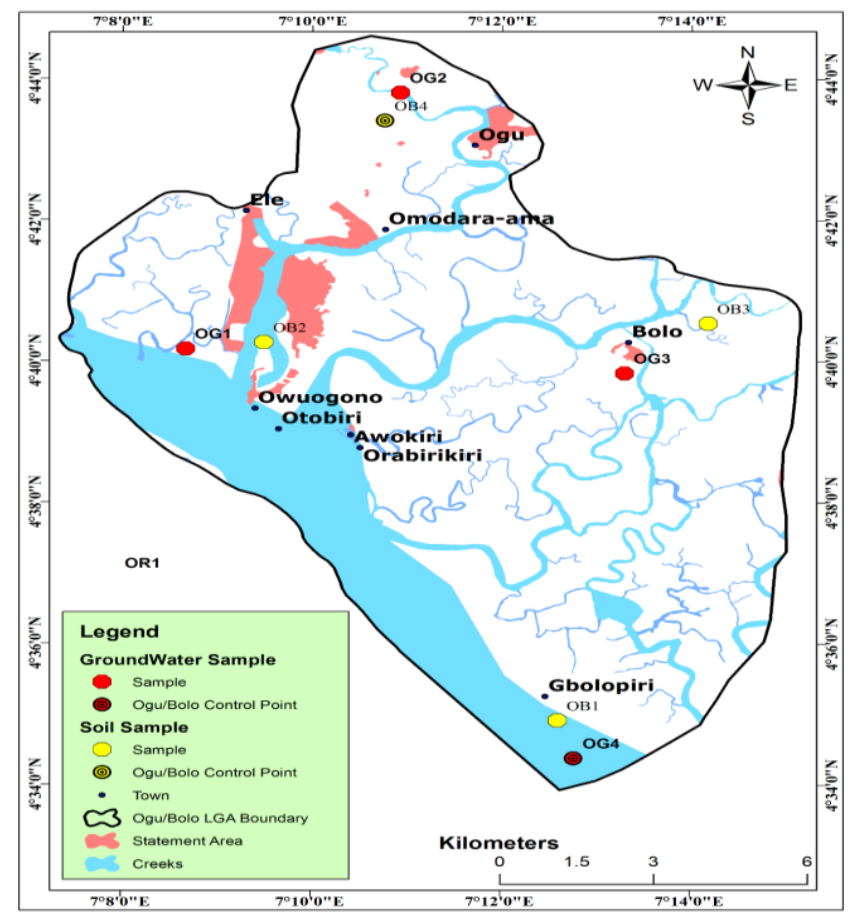

Figure 2: Ogu/Bolo Sample Locations.

and $4^{\circ} 32^{\prime} 22.202 " \mathrm{~N}$ and longitude $6^{\circ} 57^{\prime} 50.141 \mathrm{\prime E}$ and $7^{\circ} 15^{\prime} 19.895^{\prime \prime} \mathrm{E}$ using ArcGIS 10.3. The area covers a land area of approximately 302.47 $\mathrm{km}^{2}$ (Ogu-Bolo $114.58 \mathrm{~km}^{2}$ and Okrika $187.8 \mathrm{~km}^{2}$ ) this boundary was used to mark out the study area and subsequently, contour, drainage network, settlements, utilities and other spatial features relevant to achieving the set objectives. Figure 4 shows spilled site due to Artisan refining activities. 
Citation: Nwankwoala HO, Harry MT, Amangabara GT, Warmate T (2017) Impacts of Artisanal Refining Activities on Soil and Water Quality in Parts of Okrika and Ogu-Bolo Areas of Rivers State, Nigeria. J Environ Anal Toxicol 7: 503. doi: 10.4172/2161-0525.1000503

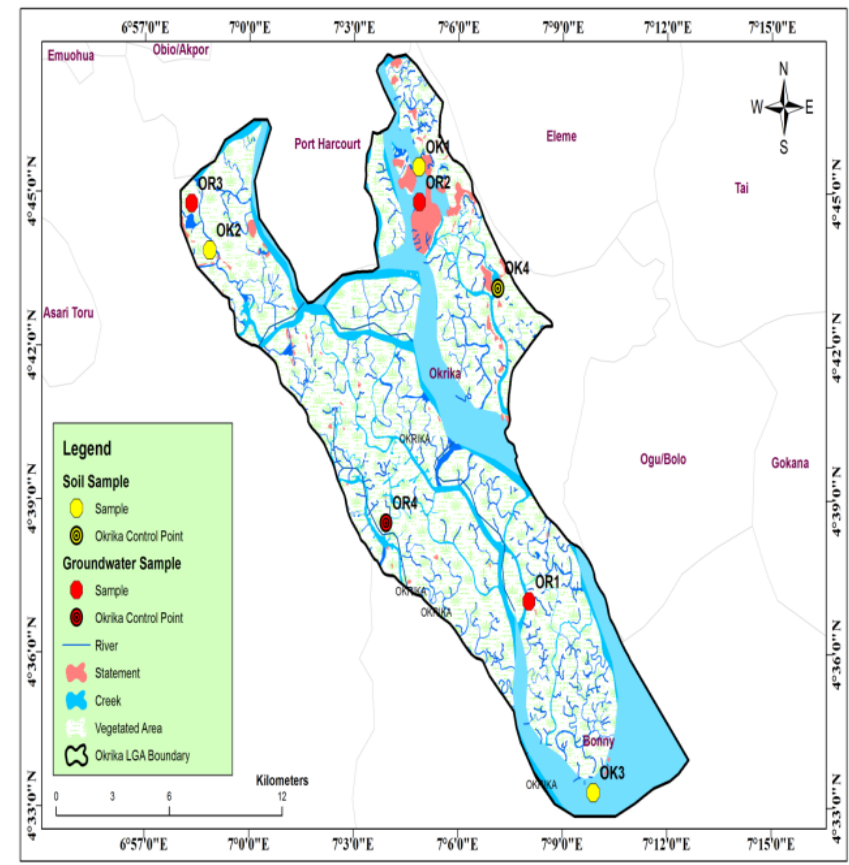

Figure 3: Okrika Sample Locations.

\begin{tabular}{|c|c|c|c|c|c|}
\hline S/N & Easting & Northing & LGA & Location & Sample type \\
\hline 1 & 7.119892 & 4.702188 & OKRIKA & OK1 & Soil \\
\hline 2 & 7.119892 & 4.702108 & OKRIKA & OK2 & Soil \\
\hline 3 & 7.11932 & 4.700406 & OKRIKA & OK3 & Soil \\
\hline 4 & 7.11891 & 4.700482 & OKRIKA & OK4 & Soil \\
\hline 5 & 7.20369 & 4.67842 & OGU-BOLO & OB1 & Soil \\
\hline 6 & 7.215291 & 4.691593 & OGU-BOLO & OB2 & Soil \\
\hline 7 & 7.11932 & 4.700406 & OGU-BOLO & OB3 & Soil \\
\hline 8 & 7.219415 & 4.76656 & OGU-BOLO & OB4 & Soil \\
\hline
\end{tabular}

Table 1: Soil Samples.

\begin{tabular}{|c|c|c|c|c|c|}
\hline S/N & Eastings & Northings & LGA & Location & Sample type \\
\hline 1 & 7.0713611 & 4.7536111 & OKRIKA & OR1 & GWATER \\
\hline 2 & 7.07136 & 4.7537111 & OKRIKA & OR2 & GWATER \\
\hline 3 & 7.0713 & 4.7419167 & OKRIKA & OR3 & GWATER \\
\hline 4 & 7.0770556 & 4.7418167 & OKRIKA & OR4 & GWATER \\
\hline 5 & 7.203478 & 4.678651 & OGU-BOLO & OG1 & GWATER \\
\hline 6 & 7.215175 & 4.691741 & OGU-BOLO & OG2 & GWATER \\
\hline 7 & 7.275823 & 4.681742 & OGU-BOLO & OG3 & GWATER \\
\hline 8 & 7.275823 & 4.67005 & OGU-BOLO & OG4 & GWATER \\
\hline
\end{tabular}

Table 2: Water Samples.

\section{Analytical methods}

The Digital Elevation Model was created from the elevation data obtained from Short Radar Thematic Mapper (SRTM) satellite image and contour extracted from the topographic map. This was achieved by turning on hill shading in the layer properties dialog box by choosing the stretched renderer and checking use hill shade effect (color ramp) to represent various elevation ranges. Triangulated Irregular Network (TIN) were generated from contour (with $\mathrm{Z}$ attribute value) and used to generate digital elevation model (DEM). Slope, Flow accumulation, flow direction was produced from the DEM using the Arc GIS 10.3 3-D analyst tool function of Arc GIS Version 10.3. Watershed and other

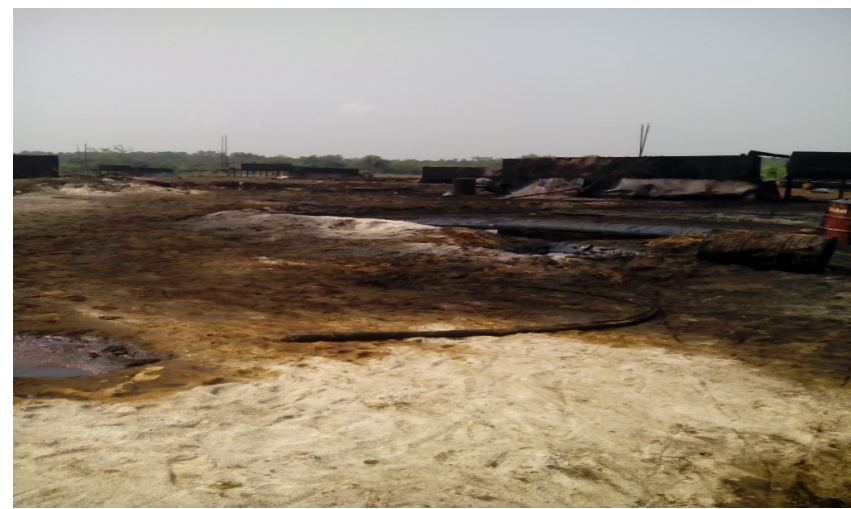

Figure 4: Field photograph showing spilled site due to Artisan refining activities.

drainage morphometric analysis were generated from drainage map, while land use or land cover and its class statistics were generated from the Land sat image covering. The slope of the study area was derived and modelled by using digital elevation model data, data-set using create slope tool, and the percentage (\%) units were included to display the slope.

The spatial resolution of the Digital Elevation Model (DEM) used for this work was $15 \mathrm{~m}$, and it was gotten out of SRTM data. The ArcGIS 10.13-D surface analysis was used to generate the TIN and slope of the area in percentage while the three 3-D Analyst in ArcScene was used to generate the 3-D visualization of the Groundwater area. From the 3-D visualization the elevation profile graphs were generated. The elevation profile graphs are cross sectional chart with elevation plotted against distance; this gives terrain explanation of a selected line of sight over a set distance.

\section{Results and Discussion}

\section{Water quality index model}

Water quality index is a 100 point scale that summarizes results from a total of different measurements when complete. It is a dimensionless number that combines multiple water-quality factors into a single number by normalizing values to subjective rating curves [10]. Factors to be included in WQI model could vary depending upon the designated water uses and local preferences. Some of these factors based on this study includes Polycyclic Aromatic Hydrocarbon (PAH), Total Petroleum Hydrocarbon (TPH), Benzene Toluene Ethyl Benzene Xylene (BTEX), Iron (Fe), Zinc (Zn), Copper $(\mathrm{Cu})$, Lead $(\mathrm{Pb})$, Hydrocarbon Utilizing Bacteria (HUB), Chloride $(\mathrm{Cl})$, Nitrate $(\mathrm{Ni})$, Sulphate $\left(\mathrm{SO}_{4}\right), \mathrm{pH}$, Biological Oxygen Demand (BOD), Chemical Oxygen Demand (COD), Turbidity, Dissolved Oxygen (DO), Temperature etc. These parameters occur in different ranges and expressed in different units Table 3 shows the descriptive statistics of water quality analysis results in the area. The WQI takes the complex scientific information of these variables and synthesizes into a single number. Graphs are used to convert field data to a $\mathrm{Q}$ or Quality Value. The Q value is then multiplied by Weighing Factor to get the Water Quality Index for that parameter. The results are then totalled to get the Overall Water Quality Index. The index equation generates a number from 1 to 100 , with 1 being the poorest and 100 indicating the best quality of water. Within this range, designations is set to classify the quality of water as poor, marginal, fair, good or excellent [11-13]. 
Citation: Nwankwoala HO, Harry MT, Amangabara GT, Warmate T (2017) Impacts of Artisanal Refining Activities on Soil and Water Quality in Parts of Okrika and Ogu-Bolo Areas of Rivers State, Nigeria. J Environ Anal Toxicol 7: 503. doi: 10.4172/2161-0525.1000503

Page 4 of 5

\section{Water Quality Index (WQI) interpretation}

The index equation generates a number between 1 and 100 with 1 being the poorest and 100 indicating the best water quality. Within this range, designations have been set to classify water quality as poor, marginal, fair, good and excellent. The designations can be seen in Table 4 while Table 5 shows the water quality rating. Table 6 also shows the general contamination rating of Okrika and Ogu-Bolo. Figure 5 is the general contamination graph rating of Okrika and Ogu/Bolo. Figure 6 shows the Pie Chart of general Contamination in the area as well as the contamination map of the area (Figure 7).

\section{Conclusion}

Results of this study, has shown that water within the study area is not suitable for drinking as well as for other domestic purposes. The study also reveals that there are negative effects of bunkering and

\begin{tabular}{|c|c|c|c|c|c|c|c|}
\hline Parameter & Min & Max & Mean & $\begin{array}{c}\text { Standard } \\
\text { Deviation }\end{array}$ & Variance & $\begin{array}{c}\text { NESREA } \\
\text { Limit }\end{array}$ & $\begin{array}{c}\text { WHO (2011) } \\
\text { mg/l }\end{array}$ \\
\hline $\mathrm{Cu}$ & - & - & - & & & 1.00 & 5.00 \\
\hline $\mathrm{Fe}$ & 0.81 & 0.21 & 0.38 & 0.32 & 0.10 & 0.50 & 0.30 \\
\hline $\mathrm{Zn}$ & 0.09 & 0.20 & 0.14 & 0.06 & 0.00 & 0.05 & 5.00 \\
\hline $\mathrm{Temp}$ & 28.70 & 30.10 & 29.93 & 0.98 & 0.96 & - & 28 \\
\hline $\mathrm{Cl}$ & 57.39 & 85.36 & 70.99 & 26.14 & 683.08 & - & $200-300$ \\
\hline $\mathrm{pH}$ & 5.70 & 6.50 & 6.1 & 0.51 & 0.26 & $6.50-8.50$ & $6.50-8.50$ \\
\hline $\mathrm{DO}$ & 1.90 & 2.30 & 3.0 & 0.76 & 0.57 & 40.00 & - \\
\hline Turbidity & 15.70 & 18.20 & 17.1 & 9.29 & 65.60 & - & 4.00 \\
\hline COD & 2.10 & 2.30 & 2.2 & 0.67 & 0.45 & 30.00 & - \\
\hline
\end{tabular}

Table 3: Descriptive statistics of water quality analysis results.

\begin{tabular}{|c|c|}
\hline Factor & Weight \\
\hline Dissolved Oxygen (DO) & 0.1 \\
\hline Faecal coliform & 0.1 \\
\hline $\mathrm{pH}$ & 0.09 \\
\hline Biological Oxygen Demand (BOD) & 0.09 \\
\hline Turbidity & 0.08 \\
\hline Total Petroleum Hydrocarbon (TPH) & 0.07 \\
\hline Temperature & 0.07 \\
\hline Polycyclic Aromatic Hydrocarbon (PAH) & 0.05 \\
\hline Iron $(\mathrm{Fe})$ & 0.05 \\
\hline Chemical Oxygen Demand (COD) & 0.05 \\
\hline Lead $(\mathrm{Pb})$ & 0.04 \\
\hline Chloride $(\mathrm{Cl})$ & 0.04 \\
\hline Benzene Toluene Ethylbenzene Xylene (BTEX) & 0.03 \\
\hline Zinc $(Z n)$ & 0.03 \\
\hline Copper (Cu) & 0.03 \\
\hline Hydrocarbon Utilizing Bacteria (HUB) & 0.03 \\
\hline Nitrate & 0.03 \\
\hline \multirow[t]{2}{*}{ Sulphate $\left(\mathrm{SO}_{4}\right)$} & 0.02 \\
\hline & 1 \\
\hline
\end{tabular}

Table 4: Weighting Factors for Different Participating Parameter.

\begin{tabular}{|c|c|}
\hline Water Quality Index Range & Water Quality Rating \\
\hline $90-100$ & Excellent \\
\hline $70-89$ & Good \\
\hline $50-69$ & Medium \\
\hline $25-49$ & Bad \\
\hline $0-24$ & Very Bad \\
\hline
\end{tabular}

Table 5: Water Quality Rating [11,12]. artisan refining on the aquifer, and the contaminants are flowing at a very faster rate into the aquifer as a result of the elevation. The physicochemical analysis on soil and water revealed poor water and soil. Water analysis showed high concentration of Fe and $\mathrm{Zn}$ which made the water in such area unsuitable for drinking. Also, the soil samples recorded high levels of crude content from $1 \mathrm{~m}$, with concentration reducing with depth up to $3 \mathrm{~m}$. Therefore, the following recommendations are made:

(i) Geochemical analysis of water samples should be carried out regularly to determine any future pollution of the water due to the activities in the area.

(ii) Appropriate water treatment of borehole should be done.

\begin{tabular}{|c|c|c|c|c|c|}
\hline \multicolumn{2}{|c|}{ Rank } & \multirow{2}{*}{$\begin{array}{l}\begin{array}{c}\text { Area } \\
\left(\mathrm{Km}^{2}\right)\end{array} \\
23.59\end{array}$} & \multirow{2}{*}{$\begin{array}{l}\text { Ratio } \\
0.06\end{array}$} & \multirow{2}{*}{\begin{tabular}{r|}
$\%$ \\
5.71
\end{tabular}} & \multirow[t]{2}{*}{ Community } \\
\hline $\begin{array}{l}\text { Very } \\
\text { Good }\end{array}$ & $\geq 48-56$ & & & & \\
\hline Good & $43.8-47.9$ & 85.65 & 0.21 & 20.71 & $\begin{array}{c}\text { Agbegbeboko, Andirikiri, } \\
\text { Angalabia, Kiriama, Odirogo, } \\
\text { Sara and Tumbikubu }\end{array}$ \\
\hline Moderate & $40.6-43.7$ & 140.37 & 0.34 & 33.95 & $\begin{array}{c}\text { Boloba, Chachakiri, lyokiri, } \\
\text { and Trapukiri. }\end{array}$ \\
\hline Bad & $35.9-40.5$ & 112.56 & 0.27 & 27.22 & $\begin{array}{c}\text { Aloacha, Bilemekiri, Davidkiri, } \\
\text { Greenkiri, Obuadakiri and } \\
\text { Okungbama. }\end{array}$ \\
\hline Very Bad & $\leq 28-35.8$ & 51.29 & 0.12 & 12.40 & $\begin{array}{l}\text { Ibaka, Ibuluya, Ogbogbo, } \\
\text { Ogoloma and Okrika. }\end{array}$ \\
\hline \multicolumn{2}{|c|}{ Grand Total } & 413.46 & 1.00 & 100.00 & \\
\hline Std. dev & 46.65639104 & & & & \\
\hline
\end{tabular}

Table 6: General contamination rating of Okrika and Ogu-Bolo.

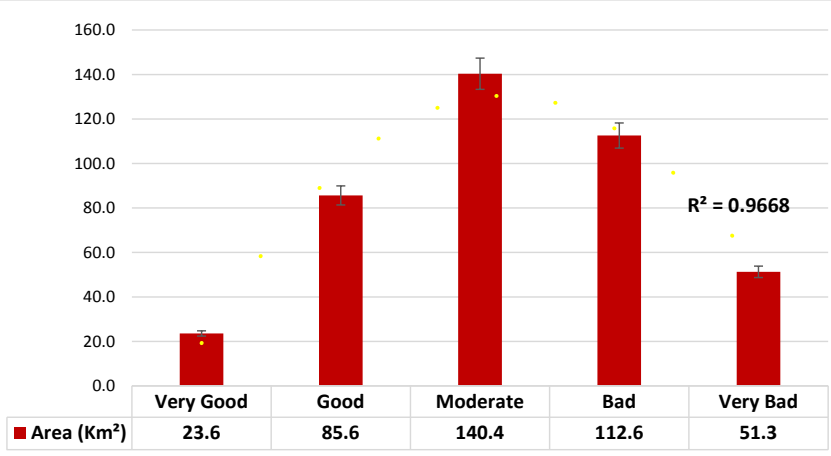

Figure 5: General contamination graph rating of Okrika and Ogu/Bolo.

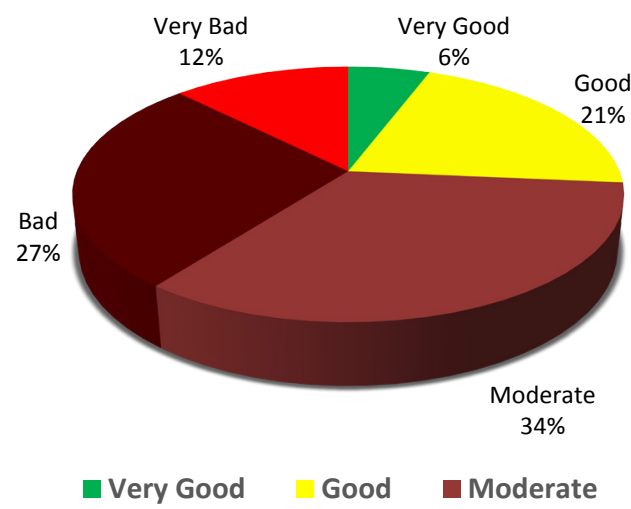

Figure 6: Pie Chart Showing General Contamination of Okrika and Ogu/Bolo. 
Citation: Nwankwoala HO, Harry MT, Amangabara GT, Warmate T (2017) Impacts of Artisanal Refining Activities on Soil and Water Quality in Parts of Okrika and Ogu-Bolo Areas of Rivers State, Nigeria. J Environ Anal Toxicol 7: 503. doi: 10.4172/2161-0525.1000503

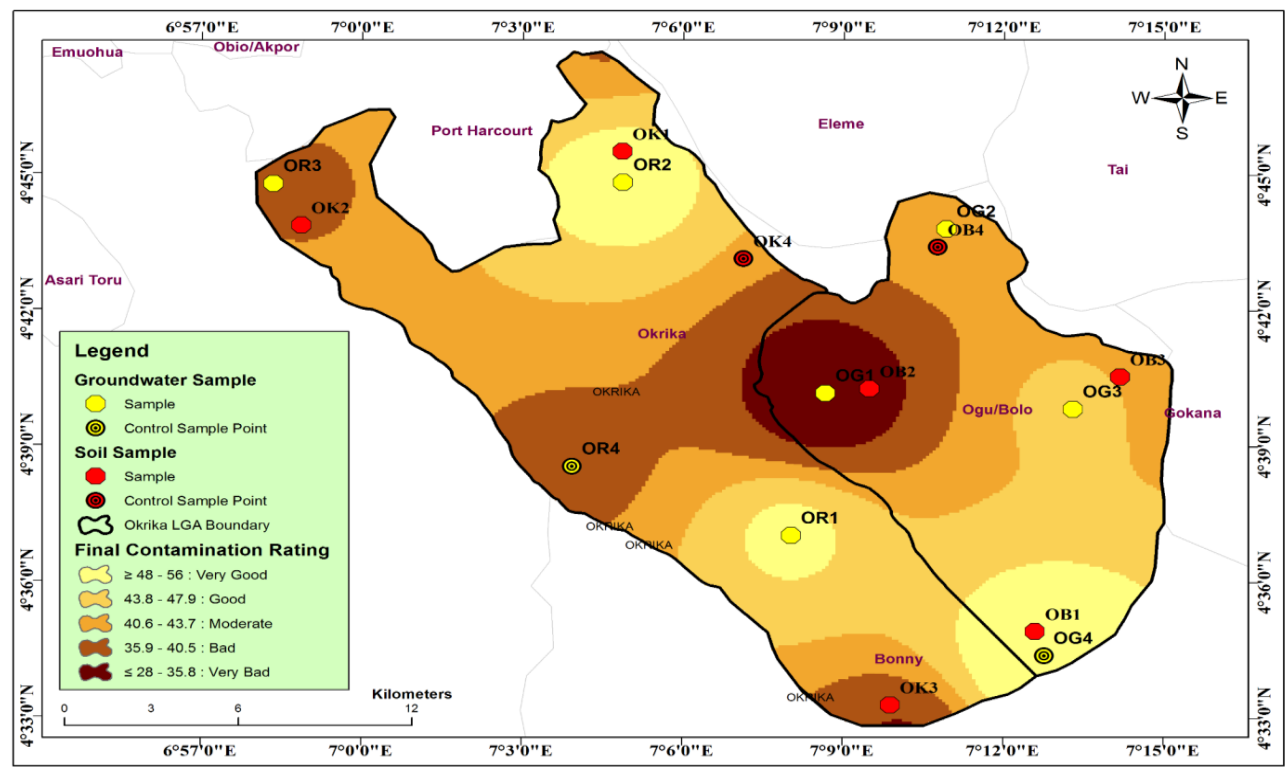

Figure 7: General contamination map rating of Okrika and Ogu/Bolo.

(iii) The higher head (highest elevation) should be considered when sitting a borehole since the contaminants will have to flow from higher to lower head.

The activities both anthropogenic and artisan refining should be discouraged.

\section{References}

1. Amangabara GT, John DN (2012) Assessing Groundwater Vulnerability to the Activities of Artisinal Refining in Bolo and Environs, Ogu/Bolo LGA, Rivers State, Nigeria. British Journal of Environment and Climate Change 2: 28-36.

2. Nwankwoala HO, Mzaga TM (2017) Geo-environmental Assessment of Hydrocarbon Contaminated Sites in parts of Central Swamp Depobelt, Eastern Niger Delta. MOJ Ecology and Environmental Science 2: 1-11.

3. Nwankwoala HO, Nwagbogwu CN (2012) Characteristics and Quality Assessment of Groundwater in Parts of Akura, South-Western Nigeria. Journal of Environmental Science and Water Resources 1: 67-73.

4. Nwankwoala HO, Ngah SA (2013) Salinity Dynamics: Trends and vulnerability of aquifers to contamination in the Niger Delta. Comprehensive Journal of Environmental and Earth Sciences 2: 18-25.

5. Avwiri GO, Ononugbo C (2011) Assessment of the Naturally Occurring Radioactive Material (Norm) Content of Hydrocarbon Exploration and Production Activities in Ogba/Egbema/Ndoni Oil/Gas Field, Rivers State, Nigeria.
6. Eluozo SN (2013) Modeling And Simulation of Mobile Bacteria Influenced by Heterogeneous Permeability and Void Ratio in Fine Sand Formation at Rumuokoro Districts of Port Harcourt Metropolis, Niger Delta of Nigeria International Journal of Environmental Engineering Science and Technology Research 1: 1-12.

7. Ojo E (1977) Climates of West Africa Heinemam, Ibadan. p: 137.

8. Nwankwoala HO, Marshal HI, Oborie E (2013) Characterization and Quantitative Indicators of Groundwater Quality in Okrika, Rivers State, Nigeria. Int Journal of Science Inventions Today 2: 319-334.

9. Offodile ME (2002) Ground water study and Development in Nigeria. 2nd edn Mecon Geology and Services Limited, Jos, pp: 242-258.

10. Miller WW (1986) Identification of water quality differences in Nevada through index application. Journal of Environ Quality 15: 265-272.

11. Brown RM, McClelland NI, Deininger RA, Tozer RG (1970) Water and Sewage Works 117: 339

12. Ramakrishnaiah CR, Sadashivalah C, Ranganna G (2009) Assessment of water quality index for the groundwater in Tumkur Taluk, Karnataka State. Indian J Chem 6: 523-530.

13. World Health Organization (WHO) (2011) Progress Report on Drinking Water and Sanitation. Geneva: UN-WHO. 